\title{
Neuronal ceroid lipofuscinosis and arthropathy: a family study
}

\author{
ROSALYN PROOPS* AND STUART H GREEN \\ From * the Department of Clinical Genetics, Birmingham Maternity Hospital; and $\dagger$ the Institute of \\ Child Health, Birmingham
}

SUMMARY A family is described in which three children have neuronal ceroid lipofuscinosis and two of them also have an arthropathy. Clinically the children have the late infantile form but pathological evidence shows the recognised overlap with the juvenile form. A fourth child with joint involvement but with normal skin biopsies is described. It is suggested that this family have a specific form of neuronal ceroid lipofuscinosis with arthropathy and that accumulation of metabolites in this storage disease may be age dependent.

The late 19th century term 'amaurotic family idiocy' was used to describe progressive neurological diseases of childhood which had several features in common. Each was described by age of onset and was associated with psychomotor retardation, convulsions, visual failure, and fatal outcome. Two main groups can now be distinguished; the sphingolipidoses, including the gangliosidoses, where the biochemical defect is known, and the neuronal storage diseases, where the abnormal or excess storage material is present but the enzyme defect is not yet recognised. Zeman and Dyken ${ }^{1}$ suggested the term neuronal ceroid lipofuscinosis (NCL) for the latter group, referring to the accumulation of pigment with staining reactions similar to ceroid or lipofuscin, 'aging pigment'. Each group comprises several subtypes which are inherited as autosomal recessives.

\section{Case reports}

A family is described in which three, possibly four, children of a sibship of seven have late infantile NCL. In addition, the children have an arthropathy. This association has not been described previously and may represent a further subtype of NCL.

The parents are Pakistani first cousins. There was no other relevant family history and neither showed any clinical abnormality. At the time of her first pregnancy the mother was 23 years of age and the father 30 years of age. The mother attended antenatal clinics regularly and her eight children were delivered in hospital in the UK. She has had no

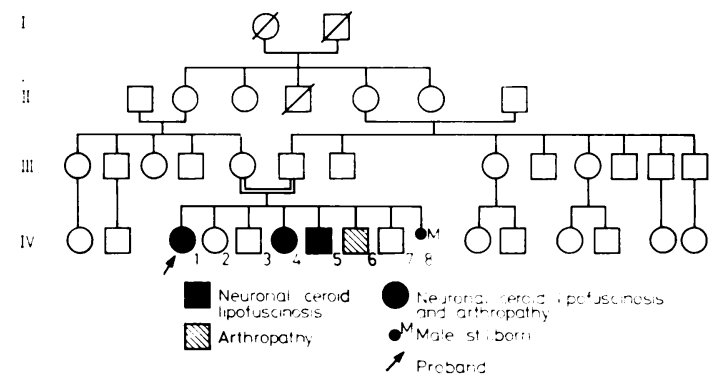

FIG 1 Family pedigree

miscarriages but her last pregnancy resulted in a stillborn boy because of placental abruption. Three children, two boys and one girl, are developmentally normal with no joint abnormalities (fig 1). The other four children are described below.

CASE 1

The first girl (IV·1) was born in June 1970, birthweight $2 \cdot 2 \mathrm{~kg}$. The pregnancy was complicated by toxaemia in the third trimester and labour was induced at 36 weeks' gestation. At one month the child was taken to Pakistan and returned to the UK with the family after 5 years. She was referred because of delay in development and failure to thrive. At 5 years her appearance was normal but height, weight, and head circumference were below the 10th centile. Both knees were enlarged, not tender, without effusions, and with full range of movement. Her wrists were affected with small effusions and held 
in a flexed position. The following year she regressed rapidly in her mental and motor development. She was unable to walk, could sit only with support, and her speech was lost. Her elbows and ankles developed effusions and fixed flexion deformities. Vision deteriorated with evidence of bilateral macular degeneration. Convulsions started and by 8 years she was having both tonic-clonic attacks and frequent myoclonic jerking of limbs and trunk. Her present state at 9 years is of an emaciated child whose only response is quietening to familiar voices. She has a profound spastic quadriplegia, bilateral optic atrophy, and a symmetrical deforming arthropathy.

$X$-rays of knees, hips, spine, and wrists showed generalised osteoporosis but no evidence of joint erosions. Electronmicroscopy of bone marrow and skin biopsy showed macrophages, fibroblasts, and nerve axons which contained enlarged lysosomes filled with membrane bound inclusions. Most of these contained closely packed, fine, lace-like filaments and a few comprised dense filaments aligned almost in parallel. These are the curvilinear and fingerprint inclusion bodies of neuronal ceroid lipofuscinosis (fig 2). The electroencephalogram was grossly abnormal with continuing runs of slow wave activity with an associated bilateral symmetrical spike element. The visual evoked response was of a simple outline with frequent spike and wave complexes in response to low rates of flash.

\section{CASE 2}

A girl (IV -4) was born in August 1973 after a normal pregnancy and delivery weighing $3.0 \mathrm{~kg}$. Her development was normal. She was referred at 4 years because of progressively swollen knees from one year. Her knees, ankles, and the proximal joints of her third and fourth fingers were enlarged and not tender but with small effusions. Within one year she regressed rapidly. She could not walk and could only utter single words. At $6 \frac{1}{2}$ years she had a developmental age of 6 months. Like her sister, she has both myoclonic and tonic-clonic convulsions. She has a spastic quadriplegia, limb and truncal ataxia, and pale optic discs. The joint abnormalities have not progressed.

$X$-rays of knees and wrists showed widening of the joint spaces but no erosions. Electronmicroscopy of synovial tissue and skin biopsy showed enlarged lysosomes within fibroblasts which were packed with both curvilinear and fingerprint type inclusions. The electroencephalogram showed some increase in slow wave activity and the VER response was consistent but reduced.

\section{CASE 3}

A boy (IV · 5) was born in April 1974 after a normal pregnancy and delivery weighing $3 \cdot 2 \mathrm{~kg}$. His development was slow. By 4 years he could walk but could not manage stairs, his speech and understanding were poor, and he was just beginning to

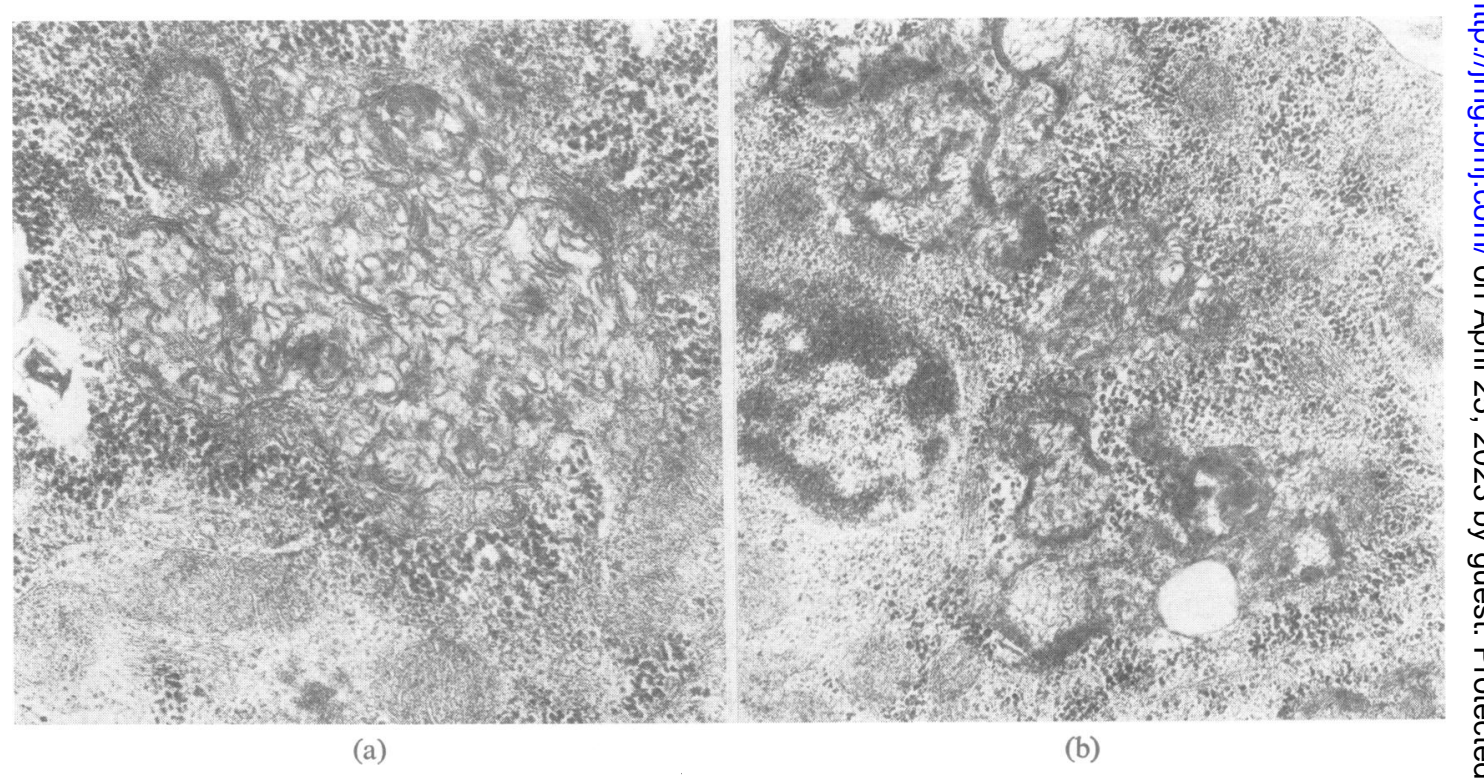

FIG 2 (a) Skin biopsy of case 1. Curvilinear inclusions and two groups of fingerprint inclusions. (Original magnification $\times 50$ 000.) (b) Skin biopsy of case 2. Predominance of fingerprint inclusions. (Original magnification $\times 33000$.) 
dress and feed himself. At $4 \frac{1}{2}$ years, although well nourished and with a normal appearance, he was uncommunicative showing little eye to eye contact. He was clumsy and hypotonic but with no evidence of an arthropathy. He has recently developed generalised convulsions.

Electronmicroscopy of skin biopsy showed fingerprint inclusion bodies within fibroblasts.

\section{CASE 4}

A boy (IV-6), born in June 1976 with a normal perinatal history and normal development, was referred at 3 years because of enlarged knees present from one year. This had not inhibited his development. He could run, skip, and ride a tricycle. The proximal joints of the third and fourth fingers of his right hand were also enlarged but not tender and without effusions.

Electronmicroscopy of skin biopsy showed fibroblasts and Schwann cells which contained occasional dense inclusions within lysosmes, but with none of the features associated with neuronal ceroid lipofuscinosis.

\section{Discussion}

The eponymous titles previously attached to this group of diseases are now only of historic interest. Four subtypes of neuronal ceroid lipofuscinosis are recognised by age of onset: infantile, late infantile, juvenile, and adult. In each type early development is normal. The clinical features are described in table 1.

Diagnosis is dependent on the clinical picture and the presence of specific inclusions within neurons. ${ }^{23}$ Cerebral biopsies are no longer justified as the inclusion bodies can be recognised in nerve tissue throughout the body, in gut, muscle, and skin. ${ }^{3-5} \mathrm{~A}$ punch or pinch skin biopsy containing dermal tissue is tolerated well by most children and is quite suit- able for this purpose. Electronmicroscopy has defined two main types of inclusion bodies within lysosomes: a lace like curvilinear form and inclusions which are likened to fingerprint patterns. Predominance of curvilinear inclusions is characteristic of the late infantile type ${ }^{6}$ and fingerprint inclusions characteristic of juvenile NCL. ${ }^{7}$ Although the abnormal or excess intracellular material can always be found, the underlying metabolic abnormality is not known. Deficiency of peroxidase ${ }^{8}$ and accumulation of retinoic acid $^{9}$ have been suggested. Neurophysiological investigations are useful in the early identification and differentiation of the subtypes of NCL (table 2). ${ }^{10}$

The three children in the family described have NCL confirmed by examination of three tissues, bone marrow, skin, and synovium. The clinical presentation is consistent and conforms to the late infantile form. However, there is some discrepancy in certain of the features.

The histological picture within the three children varies. Case 1 has predominantly curvilinear inclusions in keeping with the late infantile picture. Case 2 has mainly fingerprint inclusions but with occasional curvilinear bodies. Case 3 has fingerprint inclusions characteristic of the juvenile type. It is recognised that the electronmicroscopy findings vary and therefore it has been suggested that the clinical presentation should determine the type. ${ }^{4}$

The association of NCL with an arthropathy is interesting. In case 1 neurological symptoms preceded the joint involvement, whereas in case 2 the arthropathy was present for over 2 years before the onset of neurological impairment. The affected boy, case 3, does not have abnormal joints, but the younger boy, case 4 , has the identical distribution of joint abnormalities to his sister but is developmentally normal with no histological evidence of NCL.

None of the children has evidence of primary joint disease. ASO titres, acute and convalescent

TABLE 1 Clinical features of NCL

\begin{tabular}{|c|c|c|c|c|}
\hline Type (eponym) & Age of onset & Symptoms & Outcome & Relative frequency \\
\hline $\begin{array}{l}\text { Infantile } \\
\text { (Santavuori) }\end{array}$ & $8-18 \mathrm{mth}$ & $\begin{array}{l}\text { Myoclonus; visual } \\
\text { failure; optic atrophy; } \\
\text { retinal dystrophy; } \\
\text { psychomotor } \\
\text { retardation; ataxia }\end{array}$ & Rapidly fatal & $\begin{array}{l}\text { Very rare } \\
\text { (predominant type } \\
\text { in Scandinavia) }\end{array}$ \\
\hline $\begin{array}{l}\text { Late infantile } \\
\text { (Jansky; Bieleschowsky) }\end{array}$ & $1-4$ yr & $\begin{array}{l}\text { Regression of skills; } \\
\text { language disorders; } \\
\text { convulsions; } \\
\text { myoclonus; visual } \\
\text { failure; ataxia }\end{array}$ & & \\
\hline $\begin{array}{l}\text { Juvenile } \\
\text { (Spielmeyer and Sjogren; Batten and Vogt) }\end{array}$ & $5-10$ yr & $\begin{array}{l}\text { fallure; ataxia } \\
\text { Visual failure; } \\
\text { convulsions; dementia; } \\
\text { behavioural changes; } \\
\text { Parkinsonian-like } \\
\text { features }\end{array}$ & $\begin{array}{l}\text { within months or } \\
\text { several years }\end{array}$ & $\begin{array}{l}\text { Most requent } \\
\text { types in UK }\end{array}$ \\
\hline $\begin{array}{l}\text { Adult } \\
\text { (Kufs) }\end{array}$ & $15 \mathrm{yr}$ & $\begin{array}{l}\text { Dementia; behavioural } \\
\text { changes; convulsions }\end{array}$ & Slow progression & Exceedingly rare \\
\hline
\end{tabular}


TABLE 2 Diagnostic markers

\begin{tabular}{|c|c|c|c|}
\hline \multirow[b]{2}{*}{ Type } & \multicolumn{3}{|l|}{ Diagnostic markers } \\
\hline & $\begin{array}{l}\text { Electronmicroscopy } \\
\text { of biopsy tissue }\end{array}$ & $\begin{array}{l}\text { Electrophysiological } \\
\text { investigations }\end{array}$ & Biochemistry \\
\hline Infantile & $\begin{array}{l}\text { Normal or granular osmophilic } \\
\text { inclusions }\end{array}$ & EEG rapidly isoelectric & $\begin{array}{l}\text { Disorder of linoleic acid or } \\
\text { ? retinoic acid }\end{array}$ \\
\hline Late infantile & $\begin{array}{l}\text { Curvilinear inclusions } \\
\text { (occasional fingerprint) }\end{array}$ & EEG photosensitivity at $2-5 \mathrm{cps}$ & None known \\
\hline Juvenile & $\begin{array}{l}\text { Fingerprint inclusions } \\
\text { (occasional curvilinear) }\end{array}$ & $\begin{array}{l}\text { EEG bursts of slow waves and } \\
\text { spike and wave complexes } \\
\text { ERG early loss }\end{array}$ & None known \\
\hline Adult & $\begin{array}{l}\text { ? Fingerprint and/or osmophilic } \\
\text { inclusions } \\
\text { ? only found in brain }\end{array}$ & & None known \\
\hline
\end{tabular}

viral titres, and rheumatoid factor were negative, and circulating immune complexes (by Clq binding assay) were not detected. Nor was there evidence of other disorders, in particular mucopolysaccaridoses or lipidoses.

We suggest two possible explanations. The first is that this family demonstrates two autosomal recessive diseases which have segregated, neuronal ceroid lipofuscinosis and arthropathy of unknown origin. If this is correct, then the inclusion bodies present in the synovial tissue probably demonstrate only an aspect of the generalised neurological disorder. The second explanation is that this family has neuronal ceroid lipofuscinosis with the additional and specific involvement of synovial tissue.

The accumulation of lysosomal material secondary to an unknown metabolic abnormality is possibly age dependent. It is conceivable that within the next few years, the youngest child (IV-6) will develop progressive neurological problems and biopsies will then become positive. If so, the arthropathy may become a marker for this type of NCL.

On balance, we feel that this is more likely than the chance association of two very rare autosomal recessive diseases manifesting in this Asian family.

We thank Dr H Cameron and Miss D Standring for the electronmicroscopy reports and for the photographs, and also Professor D G Harnden for his helpful discussion.

\section{References}

1 Zeman W, Dyken P. Neuronal ceroid lipofuscinosis (Batten's disease): relationship to amaurotic family idiocy. Pediatrics 1969;44:570-83.

2 Zeman W, Donahue S. Fine structure of the lipid bodies in juvenile amaurotic idiocy. Acta Neuropathol 1963;3: 144-9.

3 Carpenter S, Karpati G, Andermann F, Jacob JC, 음 Andermann E. The ultrastructural characteristics of the abnormal cytosomes in Batten-Kuf's disease. Brain $\vec{\theta}$ 1977;100:137-56.

4 Brett EM, Lake BD. Reassessment of rectal approach to neuronathology in childhood. Arch Dis Child 1975;50: 753-62.

5 Farrell DF, Sumi SM. Skin punch biopsy in the diagnosis of juvenile neuronal ceroid lipofuscinosis. Arch Neurol 1977;34:39-44.

6 Gonatas ND, Gambetti P, Baird H. A second type of late $\mathbb{D}$ infantile amaurotic idiocy with multilamellar cytosomes. J Neuropathol Exp Neurol 1968;27:371-89.

7 Gonatas NK, Gambetti P, Tucker SH, Evangelista I, 3 Baird H. Cytoplasmic inclusions in juvenile amaurotic idiocy. J Pediatr 1969;75:796-805.

8 Armstrong D, Dimmit S, Van Wormer DE. Studies in Batten's disease. I. Peroxidase deficiency in granulocytes. Arch Neurol 1974;30:144-52.

9 Wolfs LN, Yingkin NMK, Baker RR, Carpenter S, o Andermann F. Identification of retinoyl complexes as the 3 autofluorescent component of the neuronal storage $\delta$ material in Batten's disease. Science 1977;195:1360-2.

10 Pampiglione G, Harden A. So-called neuronal ceroid lipofuscinosis. Neurophysiological studies in 60 children. J Neurol Neurosurg Psychiatry 1977;40:322-30.

Requests for reprints to Dr S H Green, Institute of Child Health, University of Birmingham, The N Nuffield Building, Francis Road, Birmingham B16 8ET. 